\title{
Efektivitas Pemberian Air Kelapa (Cocos nucifera) Sebagai Pupuk Organik Cair Terhadap Pertumbuhan Tanaman Tomat (Solanum lycopersicum)
}

\author{
Desi Indah Sari ${ }^{1}$, Efri Gresinta ${ }^{1}$, Shafa Noer ${ }^{1}$ \\ ${ }^{1}$ Fakultas MIPA, Prodi Pendidikan Biologi, Universitas Indraprasta PGRI \\ *email: Desiindahsari74@gmail.com
}

\begin{tabular}{l} 
Article History \\
\hline Received: \\
28/09/2020 \\
Revised: \\
15/10/2020 \\
Accepted: \\
20/11/2020
\end{tabular}

Kata kunci:

Air kelapa

Pupuk cair

Tomat (Solanum

Lycopersicum)

\begin{abstract}
ABSTRAK
Pupuk organik cair adalah pupuk yang berbentuk cair, salah satu jenis pupuk dari hasil pembusukan bahan-bahan organik yang berasal dari sisa tanaman, kotoran hewan. Tujuan dari penelitian ini adalah untuk mengetahui efektivitas pemberian air kelapa (Cocos nucifera) sebagai pupuk organik cair terhadap pertumbuhan tanaman tomat (Solanum lycopersicum) di Bojongsari Depok. Parameter yang diamati dalam penelitian ini adalah tinggi tanaman, jumlah daun, dan diameter batang. Metode yang digunakan adalah eksperimen dengan menggunakan Rancangan Acak Kelompok (RAK). Terdiri atas 3 (tiga) perlakuan yaitu dosis 25\%, dosis 50\% dan dosis $75 \%$ dan 1 (satu) kontrol dengan masing-masing diulang sebanyak 4 (empat) fase pengulangan. Perlakuan tersebut berupa pemberian air kelapa yang telah dicampur dengan aquadest kepada tanaman tomat (Solanum lycopersicum) yang sedang dalam fase pertumbuhan vegetatif. Hasil penelitian menunjukan bahwa, pemberian air kelapa dengan variasi dosis yang berbeda memberikan reaksi pertumbuhan yang berbeda-beda pada tanaman tomat. Dosis air kelapa yang memiliki tingkat efektivitas tertinggi terdapat pada dosis 25\%. Air kelapa memiliki manfaat pertumbuhan yang cukup efektif terhadap tinggi tanaman, sedangkan untuk jumlah daun dan diameter batang tidak terlalu mendapat pengaruh yang signifikan dibandingkan dengan perlakuan kontrol.
\end{abstract}

Keywords: Coconut water Liquid fertilizer Tomato (Solanum Lycopersicum)

\section{ABSTRACT}

Liquid organic fertilizer is a liquid fertilizer, one type of fertilizer from the decay of organic materials derived from the rest of the plant, animal manure. The purpose of this study is to know the effectiveness of the administration of coconut water (Cocos nucifera) as a liquid organic fertilizer against the growth of tomato plants (Solanum lycopersicum) in Bojongsari Depok. Parameters observed in this study are the height of the plant, the number of leaves, and the diameter of the stem. The method used is an experiment using Randomized Group Design (RAK). Consists of 3 (three) treatments namely 25\% dose, 50\% dose and $75 \%$ dose and 1 (one) control with each repeated as much as 4 (four) repetition phases. The treatment is the giving of coconut water that has been mixed with aquadest to tomato plants (Solanum lycopersicum) that are in the vegetative growth phase. The results showed that, the administration of coconut water with different dose variations gives different growth reactions in tomato plants. The dose of coconut water that has the highest effectiveness level is found at a dose of $25 \%$. Coconut water has a fairly effective growth benefit against high plants. As for the number of leaves and the diameter of the stem does not have a significant influence compared to the control treatment.
\end{abstract}

Copyright @ 2021 LPPM Universitas Indraprasta PGRI. All Right Reserved

\section{PENDAHULUAN}

Tomat (Solanum lycopersicum) merupakan sayuran buah yang termasuk tanaman semusim dan tergolong ke dalam famili Solanaceae. Tomat saat ini merupakan sayuran yang banyak diminati dan terus mengalami peningkatan setiap tahunnya serta memiliki nilai ekonomi penting bagi masyarakat Indonesia. Tomat memiliki banyak kegunaan, salah satunya digunakan untuk bahan masakan. Hampir seluruh jenis masakan di Indonesia menggunakan tomat sebagai bahan 
pembuatannya. Banyaknya manfaat tomat memberikan peluang kepada petani Indonesia untuk membudidayakan tanaman tomat sebagai penghasilan utama.

Pertumbuhan tanaman tomat (Solanum lycopersicum) membutuhkan zat-zat makanan atau unsur hara yang terdiri atas hara makro, seperti N, P, K, S, Mg, Ca, dan hara mikro, seperti $\mathrm{Mo}, \mathrm{Cu}, \mathrm{B}, \mathrm{Zn}, \mathrm{Fe}, \mathrm{Mn}$. Tomat dapat ditanam di dataran rendah maupun dataran tinggi. Tanaman ini tidak tumbuh pada tanah yang tergenang air, karena akan menyebabkan akar tomat mudah busuk dan tidak mampu menyerap zat hara dari tanah, akibatnya tanaman akan mati.

Pertumbuhan tanaman pada umumnya dipengaruhi oleh dua faktor yakni faktor dalam dan faktor luar. Faktor dalam meliputi tanaman itu sendiri, yaitu sifat yang terdapat di dalam benih tanaman, Benih tersebut dapat berasal dari biji, batang, akar, daun, dan sebagainya. Sedangkan faktor luar, meliputi iklim, suhu, kelembaban, cahaya matahari, dan angin.

Faktor lain yang menyebabkan pertumbuhan tanaman tomat rendah salah satunya ialah pemberian hormon tumbuh yang belum optimal. Upaya untuk menanggulangi permasalahan tersebut dengan cara pemberian hormon pertumbuhan. Hormon pertumbuhan tanaman yang diharapkan dapat meningkatkan hasil dan kualitas tanaman tomat salah satunya adalah pemberian air kelapa. Hormon yang terkandung dalam air kelapa yaitu auksin dan sitokinin. Kedua hormon tersebut berfungsi sebagai perangsang pertumbuhan tanaman seperti auksin dapat mempengaruhi perpanjangan batang, percabangan akar serta perkembangan buah. Sitokinin mampu mempengaruhi pertumbuhan dan deferensiasi, mendorong pembelahan sel dan mendorong perkecambahan (Amsar, 2011).

Kandungan nutrisi yang terdapat dalam air kelapa tua lebih banyak dibandingkan dengan kelapa muda, sehingga penyiraman pada tanaman tomat dalam penelitian ini menggunakan air kelapa tua. Berdasarkan kandungan nutrisi yang terdapat pada air kelapa mampu meningkatkan pertumbuhan tanaman tomat, karena kandungan yang terdapat dalam air kelapa memiliki nutrisi yang dibutuhkan tomat seperti vitamin $\mathrm{C}$, natrium, tiamin, fospor, kalsium dan riboflavin.. Air kelapa kaya akan mineral seperti, natrium $(\mathrm{Na})$, kalsium $(\mathrm{Ca})$, magnesium $(\mathrm{Mg})$, fosfor $(\mathrm{P})$, ferum $(\mathrm{Fe})$, sulfur $(\mathrm{S})$ dan cuprum $(\mathrm{Cu})$. Selain mineral, air kelapa juga kaya akan vitamin seperti asam sitrat, asam nikotinat, asam folat, riboflavin, dan thiamin (Neny, 2017).

Tujuan dari penelitian ini untuk mengetahui efektivitas pemberian air kelapa (Cocos nucifera) sebagai pupuk organik cair terhadap pertumbuhan tanaman tomat (Solanum lycopersicum).

\section{METODE PENELITIAN}

Alat dan bahan yang digunakan peneliti dalam memperoleh data sebagai berikut: polybag dengan ukuran diameter $12 \times 12 \mathrm{~cm}$ dan $20 \times 20 \mathrm{~cm}$, pisau, sekop kecil, gelas ukur, label, alat tulis, wadah air kelapa, penggaris, jangka sorong, spatula, benih tanaman tomat, air kelapa, aquadest, tanah, cocopeat dan arang sekam bakar.

Peneliti menggunakan metode penelitian kuantitatif. Desain penelitian yang digunakan adalah Rancangan Acak Kelompok (RAK) dengan 4 taraf perlakuan yang berbeda dengan 4 kali pengulangan, yaitu benih tanaman Tomat yang telah ditanam di media tanah disiram air kelapa dengan dosis 0\%, 25\%, 50\%, 75\%. Dengan ketentuan sebagai berikut:

$\mathrm{J} 0=0 \%(0 \mathrm{ml}$ air kelapa $+100 \mathrm{ml}$ aquadest $)$

$\mathrm{J} 1=25 \%$ (25 ml air kelapa $+75 \mathrm{ml}$ aquadest $)$

$\mathrm{J} 2=50 \%$ (50 $\mathrm{ml}$ air kelapa $+50 \mathrm{ml}$ aquadest $)$

$\mathrm{J} 3=75 \%$ (75 $\mathrm{ml}$ air kelapa $+25 \mathrm{ml}$ aquadest $)$

\section{HASIL DAN PEMBAHASAN}

\section{Hasil Pengamatan Tinggi Batang}

Hasil pengamatan memperlihatkan pada usia 7 hari setelah pemberian air kelapa, setelah dilakukan uji persyaratan analisis berupa uji normalitas dan uji homogenitas, pada perhitungan dengan menggunakan program SPSS, maka didapatkan pada uji normalitas sig dosis $0 \%$ $(0,528)$, dosis $25 \%(0,465)$, dosis $50 \%(0,698)$, dan dosis $75 \%(0,397)$ setiap perlakuan memiliki sig lebih besar dari 0,05 maka dikatakan data berdistribusi normal. Untuk uji homogenitas sig $(0,597)$ lebih besar dari 0,05 maka setiap perlakuan memiliki varians yang sama. Pada uji anova satu arah didapat uji $\mathrm{F}$ hitung $(2,842)$ lebih kecil dari $\mathrm{F}$ tabel $(3,41)$ sehingga $\mathrm{H}_{\mathrm{O}}$ diterima, dimana tidak ada pengaruh signifikan perlakuan pemberian air kelapa.

Pada usia 14 hari setelah pemberian air kelapa, setelah dilakukan uji persyaratan analisis berupa uji normalitas dan uji homogenitas, pada perhitungan dengan menggunakan program SPSS, maka 
didapatkan pada uji normalitas sig dosis $0 \%$ $(0,335)$, dosis $25 \%(0,370)$, dosis $50 \%(0,204)$, dan dosis $75 \%(0,077)$ setiap perlakuan memiliki sig lebih besar dari 0,05 maka dikatakan data berdistribusi normal. Untuk uji homogenitas sig $(0,189)$ lebih besar dari 0,05 maka setiap perlakuan memiliki varians yang sama. Pada uji anova satu arah didapat uji $\mathrm{F}$ hitung $(7,339)$ lebih besar dari $\mathrm{F}$ tabel $(3,41)$ sehingga $\mathrm{H}_{\mathrm{O}}$ ditolak, dimana ada pengaruh perlakuan pemberian air kelapa.

Pada usia 21 hari setelah pemberian air kelapa, setelah dilakukan uji persyaratan analisis berupa uji normalitas dan uji homogenitas, pada perhitungan dengan menggunakan program SPSS, maka didapatkan pada uji normalitas sig dosis $0 \%$ $(0,321)$, dosis $25 \%(0,820)$, dosis $50 \%(0,999)$, dan dosis $75 \%(0,215)$ setiap perlakuan memiliki sig lebih besar dari 0,05 maka dikatakan data berdistribusi normal. Untuk uji homogenitas sig $(0,083)$ lebih besar dari 0,05 maka setiap perlakuan memiliki varians yang sama. Pada uji anova satu arah didapat uji $\mathrm{F}$ hitung $(10,808)$ lebih besar dari F tabel $(3,41)$ sehingga $\mathrm{H}_{\mathrm{O}}$ ditolak, dimana ada pengaruh perlakuan pemberian air kelapa.

Pada usia 28 hari setelah pemberian air kelapa, setelah dilakukan uji persyaratan analisis berupa uji normalitas dan uji homogenitas, pada perhitungan dengan menggunakan program SPSS, maka didapatkan pada uji normalitas sig dosis 0\% $(0,633)$, dosis $25 \%(0,035)$, dosis $50 \%(0,804)$, dan dosis $75 \%(0,498)$ setiap perlakuan memiliki sig lebih besar dari 0,05 maka dikatakan data berdistribusi normal. Untuk uji homogenitas sig $(0,585)$ lebih besar dari 0,05 maka setiap perlakuan memiliki varians yang sama. Pada uji anova satu arah didapat uji $\mathrm{F}$ hitung $(7,218)$ lebih besar dari $\mathrm{F}$ tabel $(3,41)$ sehingga $\mathrm{H}_{\mathrm{O}}$ ditolak, dimana ada pengaruh perlakuan pemberian air kelapa.

Pada usia 35 hari setelah pemberian air kelapa, setelah dilakukan uji persyaratan analisis berupa uji normalitas dan uji homogenitas, pada perhitungan dengan menggunakan program SPSS, maka didapatkan pada uji normalitas sig dosis $0 \%$ $(0,707)$, dosis $25 \%(0,931)$, dosis $50 \%(0,204)$, dan dosis $75 \%(0,113)$ setiap perlakuan memiliki sig lebih besar dari 0,05 maka dikatakan data berdistribusi normal. Untuk uji homogenitas sig $(0,128)$ lebih besar dari 0,05 maka setiap perlakuan memiliki varians yang sama. Pada uji anova satu arah didapat uji $\mathrm{F}$ hitung $(24,652)$ lebih besar dari F tabel $(3,41)$ sehingga $\mathrm{H}_{\mathrm{O}}$ ditolak, dimana ada pengaruh perlakuan pemberian air kelapa.

Uji Effect Size digunakan untuk mengetahui seberapa besar efektivitas air kelapa terhadap pertumbuhan tanaman tomat (Solanum lycopersicum) uji statistik lanjut yang di gunakan untuk mengukur berapa efektif perlakuan adalah uji Effect Size.

Berdasarkan perhitungan tinggi tanaman tomat selama 35 hari perlakuan pemberian air kelapa, diperoleh nilai effect size sebesar 0,3. Nilai effect size tersebut berdasarkan tabel interpretasi effect size menunjukan bahwa treatment yang di lakukan peneliti memberikan pengaruh terhadap pertumbuhan tanaman tomat dengan kategori rendah. Hal ini berarti bahwa penggunaan air kelapa memiliki tingkat keefektivan yang kurang terhadap pertumbuhan tinggi tanaman tomat. Hasil analisis statistik menunjukan bahwa pemberian air kelapa dosis $25 \%$ memberikan hasil rata-rata tinggi tanaman yang lebih baik jika dibandingkan pemberian air kelapa pada dosis yang berbeda (Gambar 1).

\section{Hasil Pengamatan Jumlah Daun}

Jumlah pengamatan memperlihatkan pada usia 7 hari setelah pemberian air kelapa, setelah dilakukan uji persyaratan analisis berupa uji normalitas dan uji homogenitas, pada perhitungan dengan menggunakan program SPSS, maka didapatkan pada uji normalitas sig dosis $0 \%$ $(0,123)$, dosis $25 \%(0,161)$, dosis $50 \%(0,051)$ dan dosis $75 \%(0,850)$ setiap perlakuan memiliki sig lebih besar dari 0,05 maka dikatakan data berdistribusi normal. Untuk uji homogenitas sig $(0,745)$ lebih besar dari 0,05 maka setiap perlakuan memiliki varians yang sama. Pada uji anova satu arah didapat uji $\mathrm{F}$ hitung $(3,695)$ lebih besar dari $\mathrm{F}$ tabel $(3,41)$ sehingga $\mathrm{H}_{\mathrm{O}}$ ditolak, dimana ada pengaruh perlakuan pemberian air kelapa. 


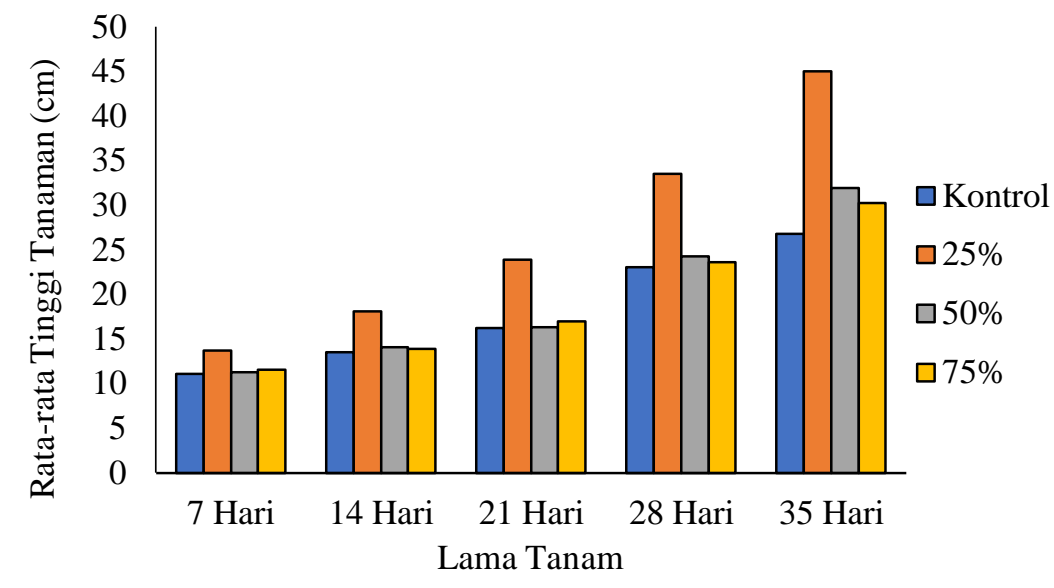

Gambar 1. Rata-rata tinggi batang tanaman tomat (Solanum lycopersicum)

Pada usia 14 hari setelah pemberian air kelapa, setelah dilakukan uji persyaratan analisis berupa uji normalitas dan uji homogenitas, diperoleh nilai uji normalitas sig dosis $0 \%(0,240)$, dosis $25 \%$ $(0,572)$, dosis $50 \%(0,062)$ dan dosis $75 \%(0,995)$ setiap perlakuan memiliki sig lebih besar dari 0,05 maka dikatakan data berdistribusi normal. Untuk uji homogenitas sig $(0,885)$ lebih besar dari 0,05 maka setiap perlakuan memiliki varians yang sama. Pada uji anova satu arah didapat uji F hitung $(1,912)$ lebih kecil dari $\mathrm{F}$ tabel $(3,41)$ sehingga $\mathrm{H}_{\mathrm{O}}$ diterima, dimana tidak ada pengaruh signifikan perlakuan pemberian air kelapa.

Pada usia 21 hari setelah pemberian air kelapa, setelah dilakukan uji persyaratan analisis berupa uji normalitas dan uji homogenitas, diperoleh nilai uji normalitas sig dosis $0 \%(0,195)$, dosis $25 \%$ $(0,572)$, dosis $50 \%(0,272)$ dan dosis $75 \%(0,100)$ setiap perlakuan memiliki sig lebih besar dari 0,05 maka dikatakan data berdistribusi normal. Untuk uji homogenitas sig $(0,867)$ lebih besar dari 0,05 maka setiap perlakuan memiliki varians yang sama. Pada uji anova satu arah didapat uji F hitung $(2,424)$ lebih kecil dari $\mathrm{F}$ tabel $(3,41)$ sehingga $\mathrm{H}_{\mathrm{O}}$ diterima, dimana tidak ada pengaruh signifikan perlakuan pemberian air kelapa.

Pada usia 28 hari setelah pemberian air kelapa, setelah dilakukan uji persyaratan analisis berupa uji normalitas dan uji homogenitas, diperoleh nilai uji normalitas sig dosis $0 \%(0,764)$, dosis $25 \%$ $(0,798)$, dosis $50 \%(0,677)$ dan dosis $75 \%(0,084)$ setiap perlakuan memiliki sig lebih besar dari 0,05 maka dikatakan data berdistribusi normal. Untuk uji homogenitas sig $(0,972)$ lebih besar dari 0,05 maka setiap perlakuan memiliki varians yang sama. Pada uji anova satu arah didapat uji F hitung
$(3,032)$ lebih kecil dari $\mathrm{F}$ tabel $(3,41)$ sehingga $\mathrm{H}_{\mathrm{O}}$ diterima, dimana tidak ada pengaruh signifikan perlakuan pemberian air kelapa.

Pada usia 35 hari setelah pemberian air kelapa, setelah dilakukan uji persyaratan analisis berupa uji normalitas dan uji homogenitas, diperoleh nilai uji normalitas sig dosis $0 \%(0,502)$, dosis $25 \%(0$, $458)$, dosis $50 \%(0,182)$ dan dosis $75 \%(0,161)$ setiap perlakuan memiliki sig lebih besar dari 0,05 maka dikatakan data berdistribusi normal. Untuk uji homogenitas sig $(0,401)$ lebih besar dari 0,05 maka setiap perlakuan memiliki varians yang sama. Pada uji anova satu arah didapat uji $\mathrm{F}$ hitung $(4,374)$ lebih besar dari $\mathrm{F}$ tabel $(3,41)$ sehingga $\mathrm{H}_{\mathrm{O}}$ ditolak, dimana ada pengaruh perlakuan pemberian air kelapa.

Uji Effect Size digunakan untuk mengetahui seberapa besar efektivitas air kelapa terhadap pertumbuhan tanaman tomat (Solanum lycopersicum) uji statistik lanjut yang di gunakan untuk mengukur berapa efektif perlakuan adalah uji effect size.

Berdasarkan perhitungan jumlah daun tanaman tomat selama 35 hari perlakuan pemberian air kelapa, diperoleh nilai effect size sebesar 0,09. Nilai effect size tersebut berdasarkan tabel interpretasi effect size menunjukan bahwa treatment yang di lakukan peneliti memberikan pengaruh terhadap pertumbuhan tanaman tomat dengan kategori sangat rendah. Hal ini berarti bahwa penggunaan air kelapa tidak efektif terhadap pertumbuhan jumlah daun tanaman tomat. Hasil analisis data secara statistik, dosis pemberian air kelapa terhadap jumlah daun tanaman tomat terlihat jelas pada dosis 25\% (Gambar 2). 


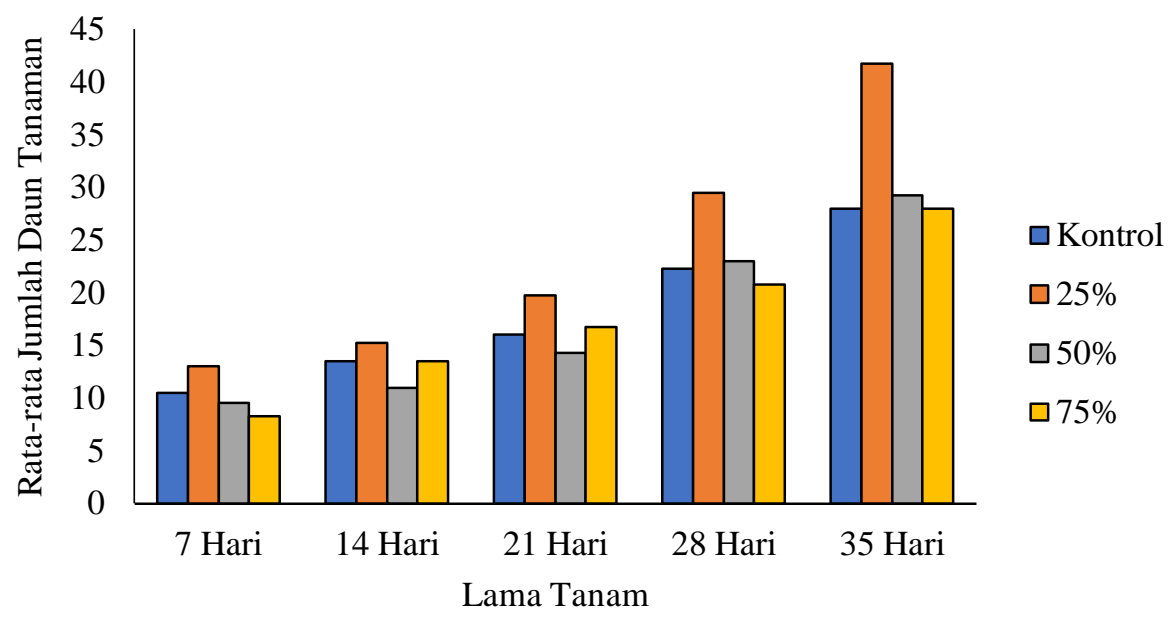

Grafik 2. Rata-rata jumlah daun tanaman tomat (Solanum lycopersicum)

\section{Hasil Pengamatan Diameter Batang}

Hasil pengamatan pada usia 7 hari setelah pemberian air kelapa, uji normalitas sig dosis $0 \%$ $(0,195)$, dosis $25 \%(0,972)$, dosis $50 \%(0,406)$ dan dosis $75 \%(0,972)$ setiap perlakuan memiliki sig lebih besar dari 0,05 maka dikatakan data berdistribusi normal. Untuk uji homogenitas sig $(0,941)$ lebih besar dari 0,05 maka setiap perlakuan memiliki varians yang sama. Pada uji anova satu arah didapat uji $\mathrm{F}$ hitung $(2,305)$ lebih kecil dari $\mathrm{F}$ tabel $(3,41)$ sehingga $\mathrm{H}_{\mathrm{O}}$ diterima, dimana tidak ada pengaruh signifikan perlakuan pemberian air kelapa.

Pada usia 14 hari setelah pemberian air kelapa, diperoleh uji normalitas sig dosis $0 \%(0,734)$, dosis $25 \%(0,272)$, dosis $50 \%(0,195)$ dan dosis $75 \%$ $(0,572)$ setiap perlakuan memiliki sig lebih besar dari 0,05 maka dikatakan data berdistribusi normal. Untuk uji homogenitas sig $(0,396)$ lebih besar dari 0,05 maka setiap perlakuan memiliki varians yang sama. Pada uji anova satu arah didapat uji $\mathrm{F}$ hitung $(2,950)$ lebih kecil dari $\mathrm{F}$ tabel $(3,41)$ sehingga $\mathrm{H}_{\mathrm{O}}$ diterima, dimana tidak ada pengaruh signifikan perlakuan pemberian air kelapa.

Pada usia 21 hari setelah pemberian air kelapa, diperoleh uji normalitas sig dosis $0 \%(0,911)$, dosis $25 \%(0,925)$, dosis $50 \%(0,995)$ dan dosis $75 \%$ $(0,577)$ setiap perlakuan memiliki sig lebih besar dari 0,05 maka dikatakan data berdistribusi normal. Untuk uji homogenitas sig $(0,455)$ lebih besar dari 0,05 maka setiap perlakuan memiliki varians yang sama. Pada uji anova satu arah didapat uji $\mathrm{F}$ hitung $(1,635)$ lebih kecil dari $\mathrm{F}$ tabel $(3,41)$ sehingga $\mathrm{H}_{\mathrm{O}}$ diterima, dimana tidak ada pengaruh signifikan perlakuan pemberian air kelapa.
Pada usia 28 hari setelah pemberian air kelapa, diperoleh hasil uji normalitas sig dosis $0 \%(0,195)$, dosis $25 \%(0,880)$, dosis $50 \%(0,798)$ dan dosis $75 \%(0,103)$ setiap perlakuan memiliki sig lebih besar dari 0,05 maka dikatakan data berdistribusi normal. Untuk uji homogenitas sig $(0,675)$ lebih besar dari 0,05 maka setiap perlakuan memiliki varians yang sama. Pada uji anova satu arah didapat uji F hitung $(1,280)$ lebih kecil dari F tabel $(3,41)$ sehingga $\mathrm{H}_{\mathrm{O}}$ diterima, dimana tidak ada pengaruh signifikan perlakuan pemberian air kelapa.

Pada usia 35 hari setelah pemberian air kelapa, diperoleh hasil uji normalitas sig dosis $0 \%(0,115)$, dosis $25 \%(0,647)$, dosis $50 \%(0,650)$ dan dosis $75 \%(0,086)$ setiap perlakuan memiliki sig lebih besar dari 0,05 maka dikatakan data berdistribusi normal. Untuk uji homogenitas sig $(0,651)$ lebih besar dari 0,05 maka setiap perlakuan memiliki varians yang sama. Pada uji anova satu arah didapat uji F hitung $(1,068)$ lebih kecil dari F tabel $(3,41)$ sehingga $H_{O}$ diterima, dimana tidak ada pengaruh signifikan perlakuan pemberian air kelapa.

Uji Effect Size digunakan untuk mengetahui seberapa besar efektivitas air kelapa terhadap pertumbuhan tanaman tomat (Solanum lycopersicum) uji statistik lanjut yang di gunakan untuk mengukur berapa efektif perlakuan adalah uji effect size.

Berdasarkan perhitungan diameter batang tanaman tomat selama 35 hari perlakuan pemberian air kelapa, diperoleh nilai effect size sebesar 0,06. nilai effect size tersebut berdasarkan tabel interpretasi effect size menunjukan bahwa 
treatment yang di lakukan peneliti memberikan pengaruh terhadap pertumbuhan tanaman tomat dengan kategori sangat rendah. Hal ini berarti bahwa penggunaan air kelapa tidak efektif terhadap pertumbuhan diameter batang tanaman tomat (Gambar 3).

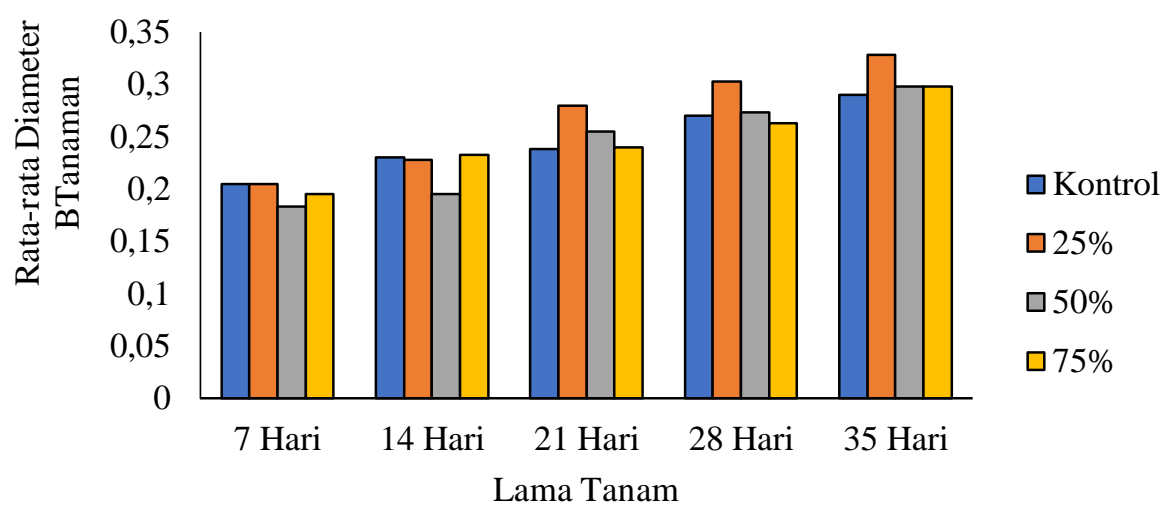

Gamabar 3. Rata-rata diameter batang tanaman tomat (Solanum lycopersicum)

Hasil analisis data secara statistik juga menunjukan bahwa pemberian air kelapa tidak berpengaruh terhadap diameter tanaman tomat. Hal ini disebabkan karena tidak berbeda nyatanya hasil yang ditunjukan oleh pemberian air kelapa terhadap diameter tanaman tomat.

Berdasarkan hasil analisis data secara statistik, dosis pemberian air kelapa berpengaruh terhadap tinggi, jumlah daun, dan diameter tanaman tomat. Hal ini menunjukan bahwa pemberian air kelapa pada dosis yang berbeda, menunjukan respon tinggi, jumlah daun, dan diameter tanaman yang berbeda pula.

Hasil analisis statistik menunjukan bahwa pemberian air kelapa dosis $25 \%$ menghasilkan ratarata tinggi tanaman tomat yang lebih baik dibandingkan dengan pemberian air kelapa pada dosis yang lainnya. Hal ini dimungkinkan karena pemberian air kelapa pada dosis $25 \%$ merupakan dosis pupuk organik cair yang paling optimum terhadap pertumbuhan tinggi tanaman tomat. Menurut Puspitasari (2010), jika suatu tanaman ditempatkan pada kondisi lingkungan yang mendukung dengan unsur hara dan mineral yang sesuai, maka tanaman tersebut akan mengalami pertumbuhan ke atas dan mengakibatkan tanaman menjadi lebih tinggi.

Dosis pemberian air kelapa terhadap jumlah daun tanaman tomat terlihat jelas pada dosis $25 \%$. Kandungan sitokinin dan auksin yang terdapat dalam air kelapa berperan penting dalam proses pembelahan sel sehingga dapat membantu pembentukan tunas. Sitokinin akan memacu sel untuk membelah secara cepat, sedangkan auksin akan memacu sel untuk memanjang (Tiwery, 2014).

Penyiraman dengan pemberian air kelapa tua mengakibatkan pertumbuhan jumlah daun yang terus mengalami peningkatan dibandingkan perlakuan tanpa penyiraman air kelapa, air kelapa tua berperan penting dalam pembentukkan serta pertumbuhan daun, karena air kelapa mempunyai hormon sitokinin yang mampu merangsang pembentukkan daun dengan maksimal (Nana, 2014).

Hasil analisis statistik juga menunjukan bahwa pemberian air kelapa tua tidak berpengaruh terhadap diameter tanaman tomat. Hal ini disebabkan karena tidak berbeda nyatanya hasil yang ditunjukan oleh pemberian air kelapa terhadap diameter tanaman tomat. Hal ini diduga karena kandungan sitokinin dan auksin yang terdapat didalam air kelapa belum mampu memacu pertumbuhan tanaman tomat dalam pembelahan dan pembesaran sel. Selain memerlukan auksin dalam memacu pertumbuhan diameter batang tanaman tomat, juga memerlukan adanya suplai unsur hara lain. Selain bekerja dalam proses pembelahan sel, kandungan hormon auksin dan sitokinin yang terdapat dalam air kelapa juga berperan dalam pembesaran diameter batang tanaman (Dwi, 2015).

\section{KESIMPULAN}

Konsentrasi pemberian air kelapa yang paling optimum terdapat pada dosis $25 \%$, dan efektivitas air kelapa sebagai pupuk organik cair terhadap 
pertumbuhan tanaman tomat (Solanum lycopersicum) yang paling signifikan didapatkan pada tinggi tanaman, tetapi tidak memberikan hasil yang signifikan terhadap jumlah daun dan diameter batang tanaman tomat.

\section{DAFTAR PUSTAKA}

Amsar, A. (2011). Pertumbuhan dan Produksi Tanaman Tomat (Lycopersicum esculentum Mill) yang diberi Pupuk Guano dan Air Kelapa. Universitas Haluoleo. Kendari.

Arimbawa, I., \& Wayan, P. (2016). Dasar Dasar Agronomi. Universitas Udayana Press: Denpasar.

Fitriani, E. (2012). Untung Berlipat Budidaya Tomat di Berbagai Media Tanam. Yogyakarta.

Indah, P., Dwi., Sampurno., \& Armaini. (2015). Pemberian air kelapa muda dan air cucian beras pada bibit karet (Hevea brasiliensis) stum mata tidur. JOM Faperta, 2 (1).

Juanda. (2013). Respon Beberapa Varietas Tanaman Tomat (Lycopersicum esculentum Mill) Terhadap Konsentrasi Pupuk Organik Cair Green Asri. Skripsi. Universitas Teuku Umar Meulaboh. Banda Aceh.

Musnamar, E. I. (2013). Pupuk Organik: Cair \& Padat, Pembuatan, Aplikasi. Skripsi. Universitas Medan Area. Medan.

Nana, S. A., \& Salamah, Z. (2014). Pertumbuhan tanaman bawang merah (Allium cepa L.) dengan penyiraman air kelapa (Cocos nucifera L.) sebagai sumber belajar biologi SMA Kelas XII. Jupemasi, 1 (1), 82-86.

Puspitasari, D. (2010). Bakteri Pelarut Fosfat Sebagai Biofertilizer Pada Pertumbuhan dan Produksi Tanaman Jagung (Zea mays L.). Skripsi. Universitas Airlangga. Surabaya.

Ratna, S. N. (2017). Pengaruh Pemberian Air Kelapa (Cocos nucifera) Terhadap Pertumbuhan Tanaman Tomat (Lycopersicum esculentum Mill). IAIN Palangka Raya. Palangka Raya

Setiawan, A. B. (2015). Induksi partenokarpi pada Tujuh genotip tomat (Solanum lycopersicum) dengan Giberelin. Tesis. UGM. Yogyakarta.

Supardi. (2013). Aplikasi Statistika dalam Penelitian Konsep Statistika yang Lebih Komprehensif. Change Publication: Jakarta.

Suryana, A. (2016). Biostatistika. Unindra: Jakarta.

Tiwery, R. R. (2014). Pengaruh penggunaan air kelapa (Cocos Nucifera) terhadap pertumbuhan tanaman sawi (Brassica juncea L.). Biopendix, 1(1), 83-91.

Wahyuni, S. (2018). Pemanfaatan Limbah Air Kelapa (Cocos nucifera L.) untuk Pembuatan Kecap dan Uji Organoleptik Sebagai Referensi Mata Kuliah Bioteknologi. UIN Ar-Raniry Darussalam. Banda Aceh. 